\title{
A Histological and Immunohistochemical Study on Testicular Changes Induced by Sliver Nanoparticles in Adult Rats and the Original Possible Protective Role of Camel Milk
}

Article

Nahla El-Eraky El-Azab and Abeer M. El-Mahalaway

Departments of Histology and Cell Biology, Faculty of Medicine, Benha University, Egypt

\begin{abstract}
Introduction: Silver nanoparticles (AgNPs) are broadly used in medicine and food industry, associated with potential toxicity in many organs. Camel milk (CM) is an excellent source of human nutrition and has many health benefits in prevention of diseases.

Aim of the work: To assess the effect of two different doses of AgNPs on the testis of adult rats and the possible protective role of CM.

Material and Methods: Forty-five adult male rats were divided into five groups, Group I: control rats, Group II: rats treated with low dose of silver nanoparticles, Group III: rats treated with high dose of AgNPs, Group IV: rats treated with low dose of AgNPs and camel milk, Group V: rats treated with high dose of AgNPs and camel milk. Testicular specimens were processed, then examined histologically and immunohistochemically. Testosterone hormonal assay were done. Morphometrical studies and statistical analysis were conducted.

Results: Group II showed mild harmful effect, while Group III had severe damaging changes on the seminiferous tubules. They showed a significant increase $(P<0.01)$ of $\alpha$-SMA, a significant decrease $(P<0.01)$ of PCNA and Bcl-2 immunostaining in cells of the seminiferous tubule and a significant decrease $(P<0.01)$ of testosterone compared to control group. Groups IV and $\mathrm{V}$ showed improvement of the changes described before.

Conclusion: Silver nanoparticles induced dose-dependent structural degenerative changes in testis. Camel milk able to attenuate biochemical and histopathological alterations caused by AgNPs by its antioxidant effect. Contact with high dosage of AgNPs is better to be avoided. Further clinical studies with human populations for long periods are still required.
\end{abstract}

Received: 09 June 2019, Accepted: 03 July 2019

Key Words: Bcl2, camel milk, PCNA, silver nanoparticles, testis.

Corresponding Author: Nahla El-Eraky El-Azab, MD, Department of Histology and Cell Biology, Faculty of Medicine, Benha University, Benha, Egypt, Tel.: +20 102763 6357, E-mail: elerakynahla@gmail.com - nahla. Eleraky@fmed.bu.edu.eg ISSN: 1110-0559, Vol. 42, No. 4

\section{INTRODUCTION}

The testis is a vital organ in the male reproductive system. It has two essential roles: synthesis of steroid hormones and production of sperms ${ }^{[1]}$. Several agents have a harmful influence on the testes, either directly, by acting on the germ cells, or indirectly, by affecting the somatic Sertoli and interstitial cells, like chemical agents, ultrafine particles, and toxic elements in environmental pollution ${ }^{[2,3]}$.

Nanoparticles (NPs) are engineered materials which consist of clusters of atoms with the size ranging from 1 to $100 \mathrm{~nm}$ where the name 'nano' means one-billionth or 10-9 units ${ }^{[4,5]}$. Nowadays, silver nanoparticles (AgNPs) have many physicochemical characteristics, such as optical, electronic, and catalytic properties, and biological effects, such as potent broad-spectrum antibacterial, antiviral, and antifungal activities ${ }^{[6,7]}$. Silver nanoparticles are promising applied nanomaterials in material science, medicine, hygiene, and food industry ${ }^{[7,8]}$. The danger of exposure to AgNPs is always rising for both workers at nanosilver industry and people using nanosilver-containing products $^{[9]}$.
These nanoparticles can reach human body by various routes such as inhalation, ingestion, dermal contact, intravenously, intraperitoneally, and subcutaneously. Silver nanoparticles are absorbed and distributed to several organs through the vascular and lymphatic system. However, excessive usage of AgNPs may be serious to human health and the environment, which can lead to obvious toxic effects of distant organs such as liver, kidney, heart, lung, thyroid, brain, and testis ${ }^{[10,11,12,13]}$.

Recently, a special interest is directed towards the use of alternative natural products for the prevention and treatment of human diseases ${ }^{[14,15]}$. Camel milk $(\mathrm{CM})$ is a rich source of well-balanced nutrients in different regions of the world ${ }^{[16]}$. It possesses unique composition and characteristics compared to the milk of other ruminant milks. It is low in cholesterol, sugar, and protein, but rich in minerals (potassium, sodium, copper, iron, zinc, and magnesium), vitamins $\mathrm{C}, \mathrm{B} 2, \mathrm{~A}$, and $\mathrm{E}$, and also lysozymes and lactoferrins in addition to insulin ${ }^{[17,18,19]}$. Camel milk is a good substitute for human milk as it does not contain $\beta$-lactoglobulin ${ }^{[20]}$. Furthermore, camel milk can be kept at 
room temperature for a longer period than other animals' $\operatorname{milk}^{[21]}$.

Camel milk is excessively used therapeutically against multiple acute and chronic health problems such as rheumatoid arthritis, inflammatory bowel disease, liver diseases, diabetes mellitus, arrhythmias, asthma, tuberculosis, wounds, anemia, and some cancers ${ }^{[22,18]}$. Besides, it has no allergic features and is easily digested and thus can be well tolerated for lactose-intolerant persons ${ }^{[14,19]}$. It has several pharmacological and biological activities such as antioxidative, antimicrobial, antiviral, antihypertensive, antihyperglycemic, antithrombotic, and immunomodulatory effects ${ }^{[23]}$.

The aim of this study was to assess the effect of two different doses of AgNPs on the testis of adult rats and the possible protective role of $\mathrm{CM}$.

\section{MATERIALS AND METHODS}

\section{Animals}

Forty-five adult male rats (150-200 g each) were utilized in this study. Rats were received from the Animal House Unit, Moshtohor Faculty of Veterinary Medicine, Benha University, Benha, Egypt. They were kept under standard environmental and laboratory conditions with free supply to water and food. This study was carried out in accordance with the Guide for the Care and Use of Laboratory Animals of the National Institutes of Health (NIH publication No. 85-23, revised 1996). All the experimental procedures were agreed upon by the local ethics committee of Faculty of Medicine, Benha University, Benha, Egypt.

\section{Materials}

Silver nanoparticles solution was provided by NanoTech Egypt for Photoelectronics ( $6^{\text {th }}$ of October City, Giza, Egypt) and coated with citrate, as suggested by the manufacturer. The concentration of AgNPs solution was $4.5 \mathrm{mg} / \mathrm{ml}$ and the size of these nanoparticles was about $25 \pm 5$ nanometers.

Camel milk was collected early in the morning from Western Desert camel farm in sterilized screw covered containers. The milk was transported in cool boxes to the laboratory, where the milk bottles were stored at $4{ }^{\circ} \mathrm{C}$.

\section{Manufacture Method of AgNPs}

Silver nanoparticles have been prepared by chemical reduction method as reported in Turkevich ${ }^{[24]}$, Lee and Meisel $^{[25]}$

\section{Transmission Electron Microscopy of AgNPs}

The shape and size of the AgNPs nanoparticles were studied by high resolution transmission electron microscope (TEM, JEOL JEM-2100) at an accelerating voltage of $200 \mathrm{kV}$. AgNPs have been liquified in $0.5 \%$ aqueous carboxymethylcellulose (Sigma-Aldrich, Munich, Germany). The resultant aqueous dispersion of these nanoparticles was dropped on carbon-coated copper grids
(200 mesh). The grids were left to dry at room temperature and examined using TEM $^{[5]}$.

\section{Experimental Design}

\section{Rats were divided into five groups}

Group I (control group) ( $\mathrm{n}=9$ ): rats were subdivided equally into three subgroups. Subgroup Ia: rats were left without any intervention. Subgroup Ib: rats were intraperitoneally injected with $0.5 \mathrm{ml}$ distilled water daily for four weeks. Subgroup Ic: rats were given $0.5 \mathrm{ml}$ of distilled water through both intraperitoneal injection and a gastric tube daily for four weeks.

Group II (group treated with low dose of silver nanoparticles) $(n=9)$ : rats were intraperitoneally injected with AgNPs in a dose of $2 \mathrm{mg} / \mathrm{kg}$ bodyweight once daily for four weeks by using insulin syring $\mathrm{e}^{[8]}$.

Group III (group treated with high dose of silver nanoparticles) $(n=9)$ : rats were injected intraperitoneally with AgNPs in a dose of $4 \mathrm{mg} / \mathrm{kg}$ bodyweight once daily for four weeks by using insulin syringe ${ }^{[8]}$.

Group IV (group treated with low dose of silver nanoparticles and camel milk) $(n=9)$ : rats were intraperitoneally injected with AgNPs in a dose of $2 \mathrm{mg} /$ $\mathrm{kg} /$ day and simultaneously received camel milk of $5 \mathrm{ml} /$ $\mathrm{rat} /$ day for four weeks through gastric tube $\mathrm{e}^{[8,14]}$.

Group V (group treated with high dose of silver nanoparticles and camel milk) $(n=9)$ : rats were intraperitoneally injected with AgNPs in a dose of $4 \mathrm{mg} / \mathrm{kg}$ /day and simultaneously received camel milk of $5 \mathrm{ml} / \mathrm{rat} /$ day for four weeks through gastric tube ${ }^{[8,14]}$.

At the end of the experiment, blood samples were collected from caudal vein of the animals of all groups for hormonal assay. Then, the animals of all groups were anesthetized by inhalation of ether and euthanized after four weeks from the onset of the experiment. The right testes were dissected out, and the testicular specimens were fixed immediately in $10 \%$ neutral buffered formalin.

\section{Histopathological Evaluations}

Paraffin sections (4-5 $\mu \mathrm{m}$ thick) were prepared, processed, and stained with HandE stain for the histological examination of the testis ${ }^{[26]}$. Other testis sections were placed on positively charged slides for immunohistochemical studies ${ }^{[27]}$.

\section{Immunohistochemistry Studies}

1. Immunohistochemical staining for detecting of alpha-smooth muscle actin ( $\alpha$-SMA): the primary antibody, monoclonal mouse anti-human $\alpha$-SMA (N 1584, Dako, Carpinteria, California, USA), was used. $\alpha$-SMA immunoexpression appeared as brown cytoplasmic staining.

2. Immunohistochemical staining for antiproliferating cell nuclear antigen (PCNA): the primary monoclonal antibody was anti-PCNA IgG antibody 
(Sigma-Aldrich Inc., U.K). PCNA appeared as brown nuclear staining.

3. Immunohistochemical staining for $\mathrm{Bcl}-2$ : the primary antibody, mouse anti-Bcl-2 monoclonal antibody (Santa Cruz Biotechnology, CA, USA), was used. Bcl-2 immunoexpression appeared as brown cytoplasmic staining.

Immunohistochemical study was conducted using the avidin-biotin peroxidase method. Diaminobenzidine (Dakopatts, Glostrup, Denmark) was used as a chromogen. The slides were washed with distilled water and finally counterstained with hematoxylin. For the negative control, the specific primary antibody was replaced by phosphatebuffered saline. The positive controls for $\alpha$-SMA and PCNA were a section from the skin, while for Bcl-2 it was a section from the tonsil.

\section{Hormonal Assay}

Hormonal assay was performed to determine testosterone (TT) using enzyme-linked immunosorbent assay (ELISA) kits (IB79174; IBL-America, Minneapolis, Minnesota, USA) according to manufacturer's instructions ${ }^{[28]}$.

\section{Determination of Oxidative Stress and Antioxidant Enzymes}

Portions of left testes were homogenized in a saline solution $(0.9 \%)$ and centrifuged at $3000 \mathrm{rpm}$ for $15 \mathrm{~min}$, and the supernatant was stored at $-20^{\circ} \mathrm{C}$. The tissue homogenate was used for quantifying of oxidative stress through estimation of malondialdehyde (MDA) using the method of Ohkawa et al. $1979^{[29]}$ and the antioxidant enzymes such as reduced glutathione (GSH) and catalase (CAT) according to Beutler et al., $1963^{[30]}$ and Aebi, $1984^{[31]}$, respectively. MDA, GSH, and CAT activities were estimated by enzymatic method, using commercial kits (Biodiagnostic, Dokki, Giza, Egypt) following the manufacturer instruction.

\section{Morphometric Analysis}

Morphometric studies were performed by means of a Leica Qwin 500 image analysis computer system (Leica Microsystems Ltd., Cambridge, UK) at the Pathology Department, Faculty of Medicine, Cairo University. Nine slides from all rats of each group $(n=9)$ were evaluated. The mean area percentage of positive immunoexpression of $\alpha$-SMA, PCNA, and Bcl-2 was assessed in 10 nonoverlapping fields of each section at $\times 400$ magnification.

\section{Statistical Analysis}

All the data collected from the hormonal assay, oxidative stress markers measurements, and morphometrics of the experiment were recorded and analyzed using IBM SPSS software for Windows, version 20 (IBM Corp., Armonk, NY, USA). One-way analysis of variance (ANOVA) with post hoc LSD test was applied to compare differences among the groups. The differences were significant at $P<0.01$.

\section{RESULTS}

Nanoparticle Characterization

TEM examination of the prepared AgNPs showed aggregation of spherical AgNPs in the size range of $25 \pm 5$ nm (Figure 1)

\section{Histological Results}

\section{HandE Stain}

Group I: Testes sections from all control subgroups showed normal histological architecture. The testicular tissue was formed of many tightly packed seminiferous tubules lined by Sertoli cells and germinal epithelium. The germinal epithelium consisted of several layers of spermatogenic cells which are formed of spermatogonia, spermatocytes, spermatids, and sperms. Spermatogonia appeared as small rounded cells with rounded nuclei present in the basal part of the tubules. Primary spermatocytes were larger in size than the spermatogonia with large rounded nuclei. Early spermatids appeared as small rounded cells with paler nuclei. Sperms were demonstrated by their long tails in the lumen of tubules. Sertoli cells appeared pyramidal in shape with large vesicular nuclei and prominent nucleoli. Each tubule was ensheathed by a definite basement membrane and surrounded by flattened myoid cells with flattened nuclei. The narrow interstitial spaces in between the tubules were occupied by the connective tissue and clusters of Leydig cells with acidophilic cytoplasm and vesicular nuclei (Figures 2a and 2b).

Group II: The sections of this group showed seminiferous tubules with apparent reduction in the number of the spermatogenic cell lines with vacuolation in some of them. The Leydig cells were found in the intact interstitial tissue (Figure 2c).

Group III: This group revealed seminiferous tubules with marked apparent reduction in number, disorganization, and vacuolation of most germinal epithelial cells. Most tubules were lined with cells that exhibited dark stained pyknotic nuclei and wide gaps between them. Some tubules had desquamated cells within their lumen. Interstitial tissue displayed few Leydig cells and vacuoles. There were congested blood vessels, distorted and detached parts of basement membrane, inflammatory cells infiltration (Figures $2 \mathrm{~d}$ and 2e).

Group IV: This group showed apparently normal seminiferous tubules surrounded by basement membrane and lined by Sertoli cells and stratified germinal epithelium. Sperms were observed in the lumen of the seminiferous tubules. Leydig cells were noticed in the normal interstitial tissue (Figure 2f).

Group V: Sections of group V showed the basal compartment of some seminiferous tubules lined by germ cells with vacuolated cytoplasm and dark nuclei. Other seminiferous tubule were seen with more or less normal spermatogenic cell lines (Figure $2 \mathrm{~g}$ ). 


\section{Immunohistochemical Stains}

\section{1-Alpha-Smooth Muscle Actin Immunohistochemical Staining}

Group I testes showed minimal brown positive $\alpha$-SMA reaction in the cytoplasm of the peritubular myoid cells (PMCs) surrounding the seminiferous tubules as well as in both the endothelium and the smooth muscle cells of the wall of blood vessels (Figure 3a). Group II showed mild positive $\alpha$-SMA immunoreaction in the interstitial tissue and seminiferous peritubular boundary tissues and around blood vessels (Figure $3 \mathrm{~b}$ ), while the reaction was highly positive in group III (Figure 3c). Group IV showed minimal positive $\alpha$-SMA immunoreaction (Figure $3 \mathrm{~d}$ ), but immunoreaction was moderate in group V (Figure 3e).

\section{2- PCNA Immunohistochemical Staining}

The control group showed many PCNA immunopositive germ cells in the seminiferous tubules (Figure 4a). Group II revealed moderate number of PCNA immunopositive germ cells (Figure 4b), while group III showed few PCNA immunopositive cells in the seminiferous tubules (Figure 4c). Group IV showed many PCNA immunopositive cells (Figure 4d), but there were a moderate number of PCNA immunopositive germ cells in the seminiferous tubules of group V (Figure 4e).

\section{3- Bcl-2 Immunohistochemical Staining}

Group I showed intense positive Bcl-2 cytoplasmic immunoreaction in cells lining the seminiferous tubule (Figure 5a), while Bcl-2 immunoreaction was moderate in group II (Figure 5b). Group III revealed minimal Bcl2 immunoreaction in cells of the seminiferous tubule (Figure 5c). Group IV showed intense positive $\mathrm{Bcl}-2$ immunoreaction (Figure 5d), but mild positive $\mathrm{Bcl}-2$ immunoreaction was seen in cells of the seminiferous tubule of group $\mathrm{V}$ (Figure 5e).

\section{Hormonal Results}

Blood testosterone measurements were expressed as mean \pm SD in all groups (Table 1 and Histogram 1). The mean value of testosterone level in rats of group II exhibited a statistically nonsignificant decrease $(p<0.01)$ as compared with the control group, but in group III it was significantly decreased $(p<0.01)$ as compared with the control group. Group IV showed nonsignificant increase $(p<0.01)$ in contrast to groups I and II. Group V showed significant decrease $(p<0.01)$ as compared to group I and significant increase $(p<0.01)$ as compared to group III.

\section{Effect on Oxidative Stress Markers}

MDA and antioxidants markers were expressed as mean \pm SD in all groups (Table 2 and Histogram 2). The mean value of MDA level demonstrated significant increase $(p<0.01)$, while a significant reduction $(p<0.01)$ in the levels of antioxidant markers such as GSH and catalase was seen in rats of groups II, III, and V as compared to control group. There were no significant $(p<0.01)$ changes detected in the levels of MDA, GSH, and catalase in group IV as compared to the control group. There was a significant decrease of MDA level $(p<0.01)$ and a significant increase in GSH and catalase levels $(p<0.01)$ in groups IV and V as compared to groups II and III, respectively.

\section{Morphometric Results}

The mean area percentage of alpha-smooth muscle actin, PCNA, and Bcl-2 immunostaining is presented in (Tables 3, 4, and 5 and in Histograms 3, 4, and 5). The mean area percentage of alpha-smooth muscle actin immunostaining was significantly increased in groups II and III compared with group I $(P<0.01)$. Group IV showed nonsignificant increase $(p<0.01)$ compared with group I. Group V showed significant increase $(p<0.01)$ compared with group I. Mean area percentage of PCNA and Bcl-2 immunostaining was significantly reduced in groups II and III in comparison to group I $(P<0.01)$. Group IV showed nonsignificant decrease $(p<0.01)$ compared with group I. Group V showed significant decrease $(p<0.01)$ in contrast with group I.

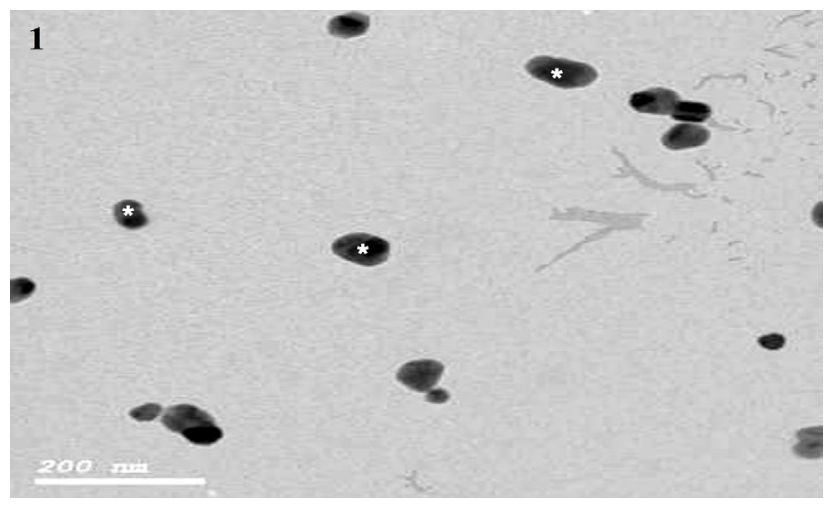

Fig. 1: An electron micrograph showing sphere shaped silver nanoparticles (AgNPs) in the size extent of $25 \pm 5 \mathrm{~nm}(*)$ (scale bars $200 \mathrm{~nm}$ ).

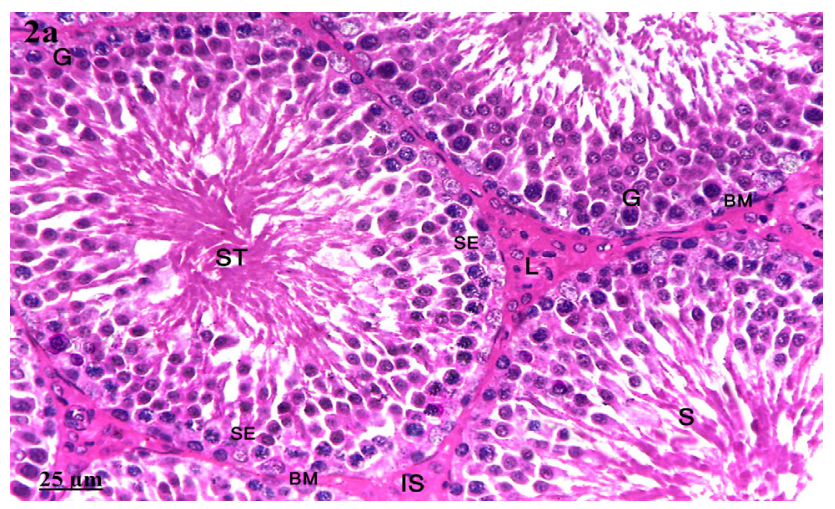

Fig. 2a: A photomicrograph of a section in the testis of group I showing normal seminiferous tubules (ST) lined by germinal epithelium (G) and Sertoli cells (SE) resting on the basement membrane (BM). Sperms (S) are seen in the lumen. Notice narrow normal interstitial spaces (IS) in between the tubules, which contain interstitial cells of Leydig (L) (HandE, $\times 400$, scale bar $=25 \mu \mathrm{m}$ ). 


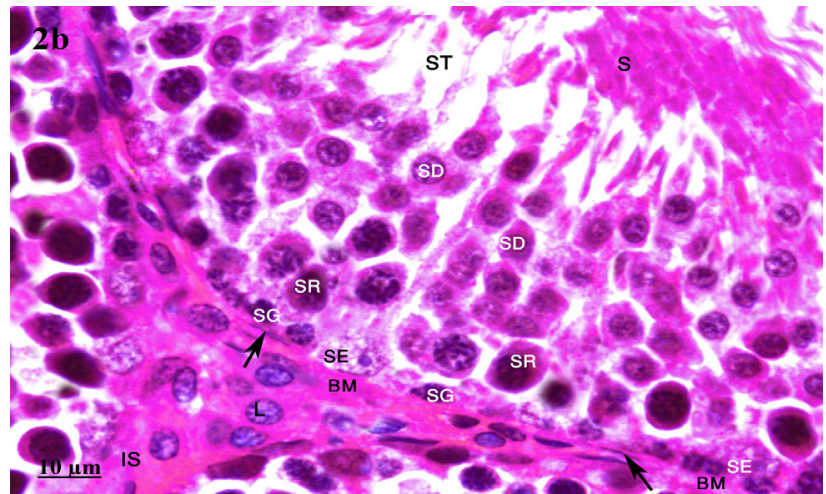

Fig. 2b: A photomicrograph of a section in the testis of group I showing part of seminiferous tubules (ST) lined by many layers of spermatogenic cells arranged in the form of spermatogonia (SG), primary spermatocytes (SR), spermatids (SD), and sperms (S), separated by Sertoli cells (SE) with large vesicular nuclei and pale staining cytoplasm resting on the basement membrane (BM). The interstitial spaces (IS) contain clusters of Leydig cells (L). Note flat myoid cells with flattened nucleus (arrow) surrounding the tubules (HandE, $\times 1000$ scale bar $=10 \mu \mathrm{m}$ )

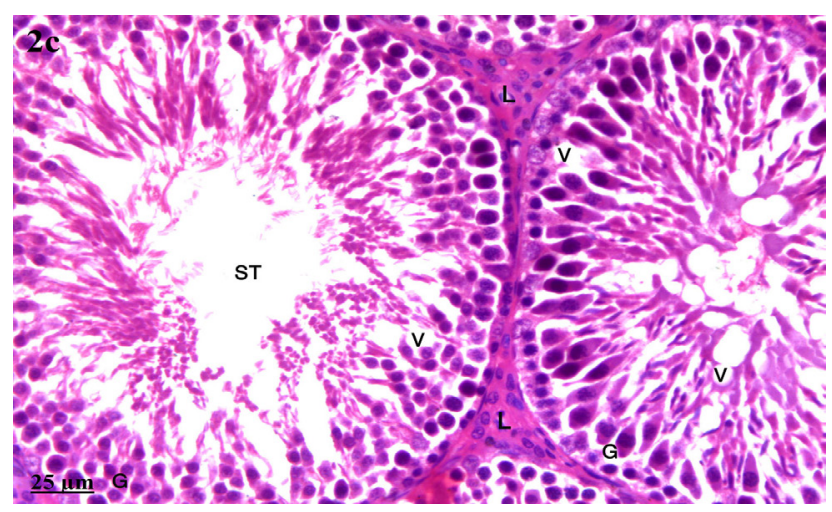

Fig. 2c: A photomicrograph of a section in the testis of group II showing seminiferous tubules (ST) with apparent reduction in the number of the spermatogenic cell lines $(\mathrm{G})$ with vacuolation $(\mathrm{V})$ in some of them. The Leydig cells (L) lie in the intact interstitial tissue (HandE, $\times 400$, scale bar $=25 \mu \mathrm{m})$

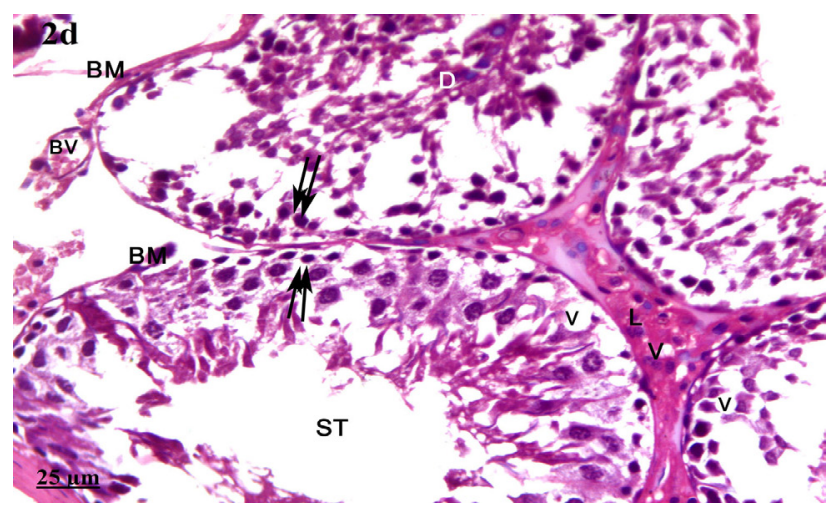

Fig. 2d: A photomicrograph of a section in the testis of group III showing seminiferous tubules (ST) with marked apparent reduction of the number, disorganization, and vacuolation (V) of most germinal epithelial cells. Most cells lining the tubules exhibit pyknotic nuclei (double arrows). Some tubules show desquamated cells (D) within its lumen. Interstitial tissue displays few Leydig cells (L) and vacuoles (V). Note distorted and detached part of basement membrane (BM) surrounding the tubules and congested blood vessels $(\mathrm{BV})(\mathrm{HandE}, \times 400$, scale bar $=25 \mu \mathrm{m})$.

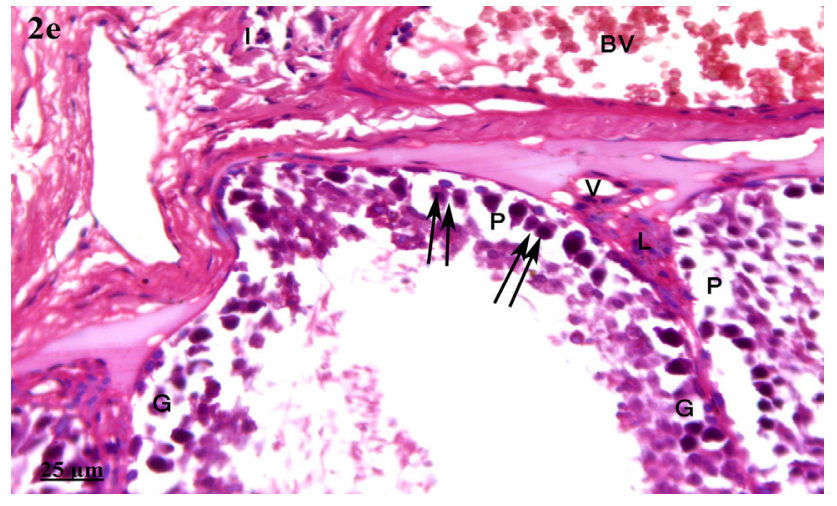

Fig. 2e: A photomicrograph of a section in the testis of group III showing marked reduction of the number of germ cells $(\mathrm{G})$; shedding and degenerating cells have dark stained nuclei (double arrows) with wide gaps $(\mathrm{P})$ between them. Note wide interstitial tissue with few Leydig cells (L) and vacuoles (V). Congested blood vessels (BV), inflammatory cells infiltration (I) (HandE, $\times 400$, scale bar $=25 \mu \mathrm{m})$.

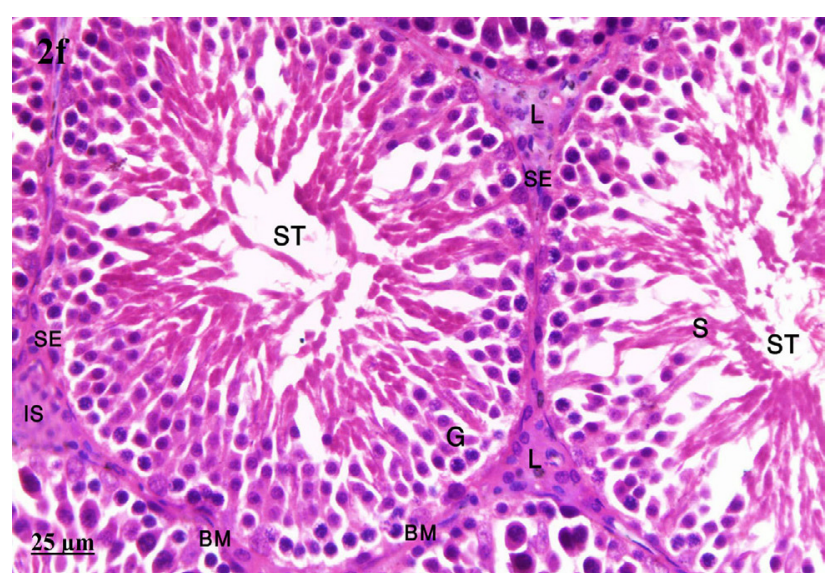

Fig. 2f: A photomicrograph of a section in the testis of group IV showing apparently normal seminiferous tubules (ST) with their lining of spermatogenic cells $(\mathrm{G})$, Sertoli cells (SE), which rest on basement membrane (BM), and sperms (S) in the lumen. Note Leydig cells (L) in the normal interstitial tissue (IS) (HandE, $\times 400$, scale bar $=25 \mu \mathrm{m}$ ).

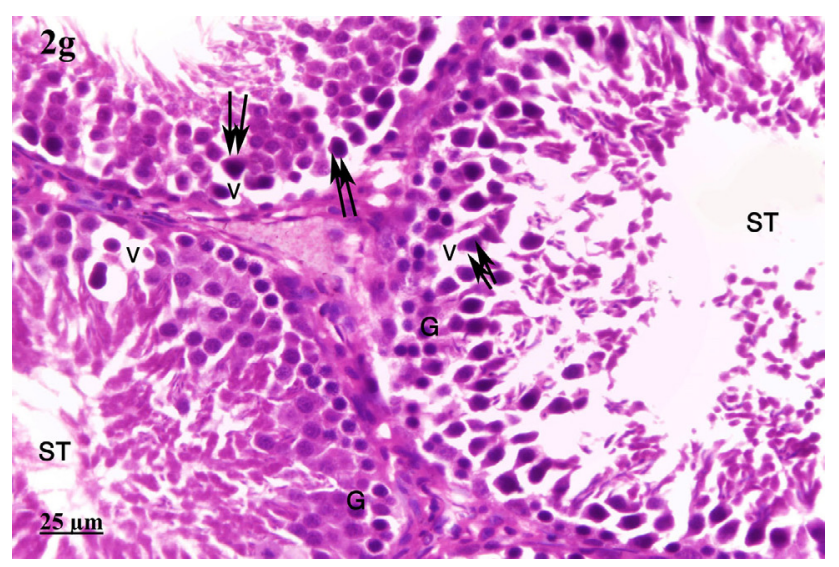

Fig. 2g: A photomicrograph of a section in the testis of group V showing the basal compartment of some seminiferous tubules (ST) lined with germ cells with vacuolated cytoplasm (V) and dark nuclei (double arrows). Other seminiferous tubule are seen with more or less normal spermatogenic cell lines $(\mathrm{G})($ HandE, $\times 400$, scale bar=25 $\mu \mathrm{m})$. 


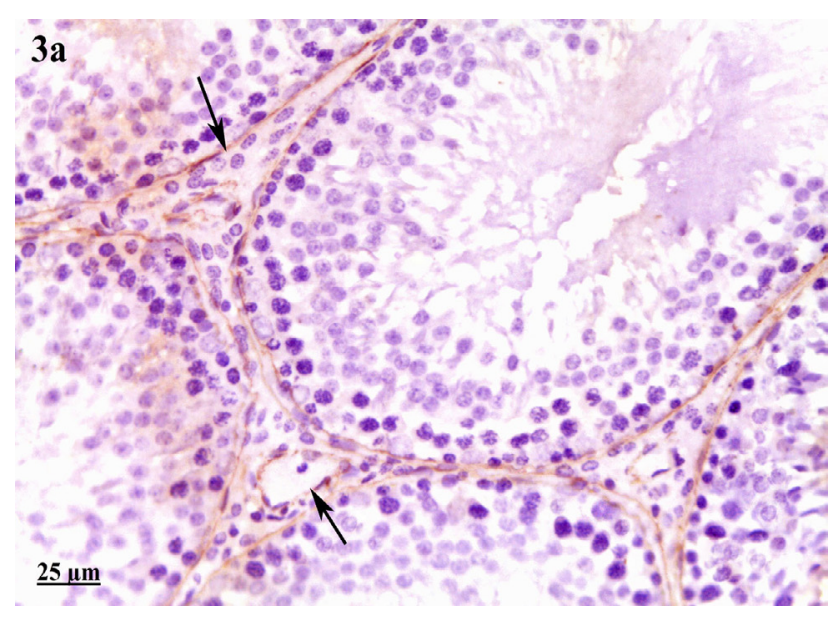

Fig. 3a: A photomicrograph of a section in the testis of group I showing minimal positive $\alpha$-SMA immunoreaction (arrow) in the seminiferous peritubular boundary tissues and around blood vessels (immunostaining for $\alpha$-SMA $\times 400$, scale bar $=25 \mu \mathrm{m}$ ).

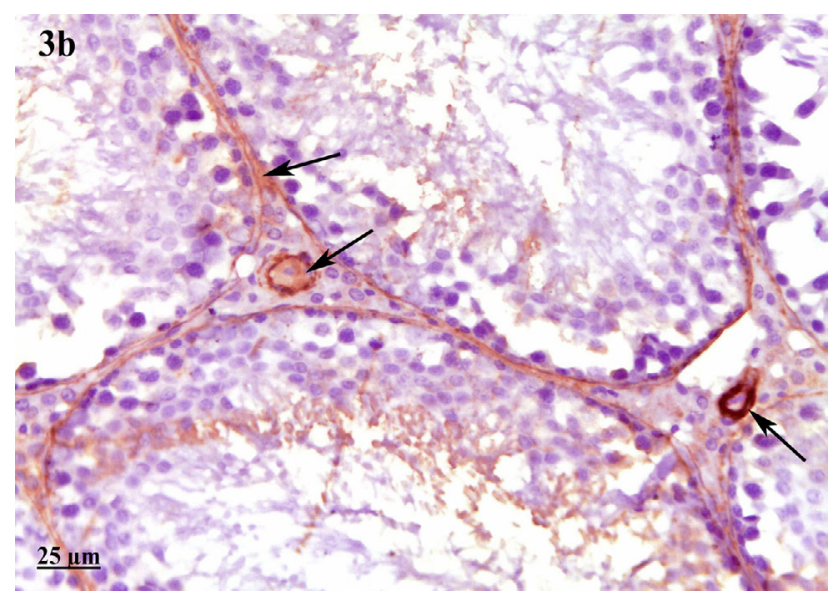

Fig. 3b: A photomicrograph of a section in the testis of group II showing mild positive $\alpha$-SMA immunoreaction (arrow) in the seminiferous peritubular boundary tissues and around blood vessels (immunostaining for $\alpha$-SMA $\times 400$, scale bar $=25 \mu \mathrm{m}$ ).

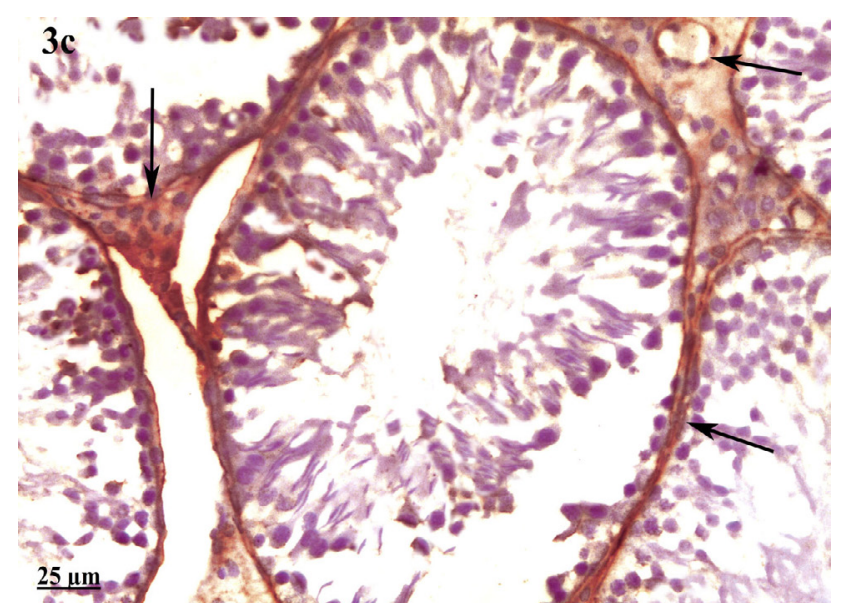

Fig. 3c: A photomicrograph of a section in the testis of group III showing highly positive $\alpha$-SMA immunoreaction (arrow) in the seminiferous peritubular boundary tissues and around blood vessels (immunostaining for $\alpha$-SMA $\times 400$, scale bar $=25 \mu \mathrm{m}$ ).

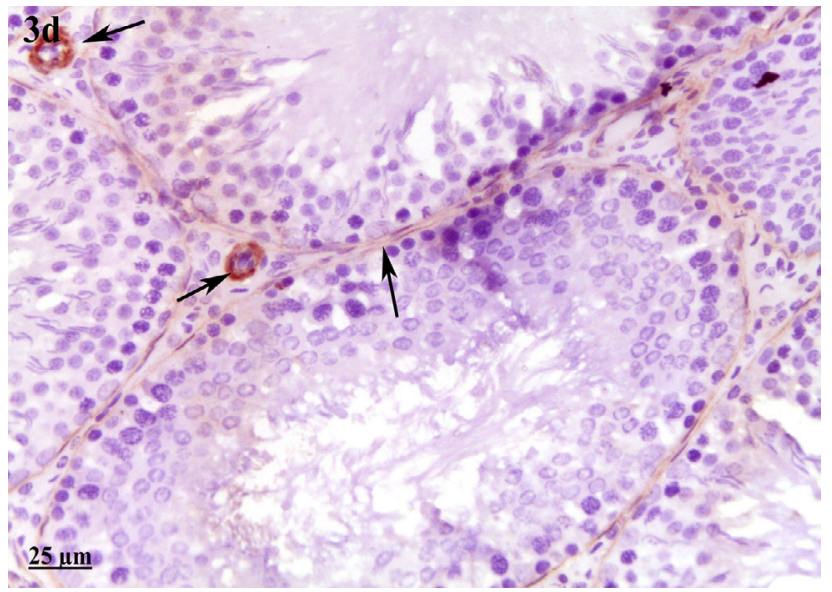

Fig. 3d: A photomicrograph of a section in the testis of group IV showing minimal positive $\alpha$-SMA immunoreaction (arrow) in the seminiferous peritubular boundary tissues and around blood vessels (immunostaining for $\alpha$-SMA $\times 400$, scale bar $=25 \mu \mathrm{m}$ ).

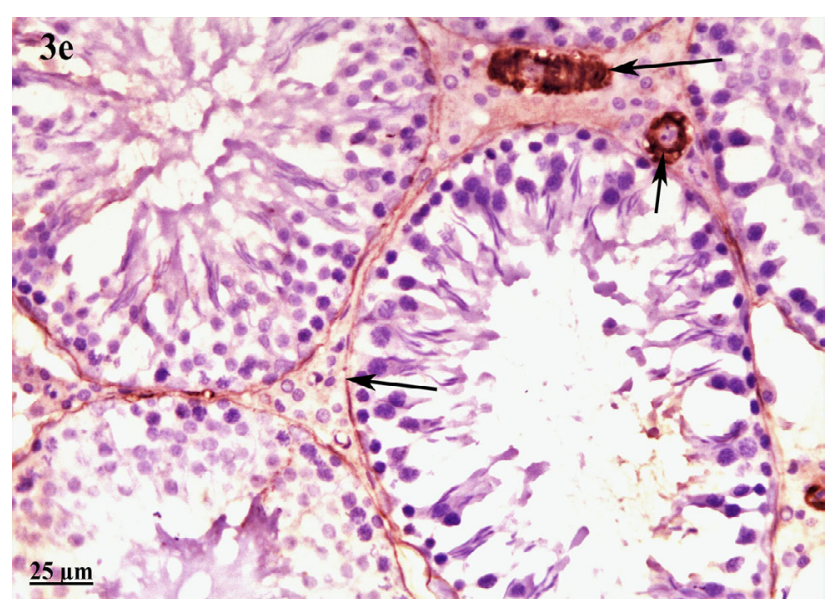

Fig. 3e: A photomicrograph of a section in the testis of group $\mathrm{V}$ showing moderate positive $\alpha$-SMA immunoreaction (arrow) in the seminiferous peritubular boundary tissues and around blood vessels (immunostaining for $\alpha$-SMA $\times 400$, scale bar $=25 \mu \mathrm{m}$ ).

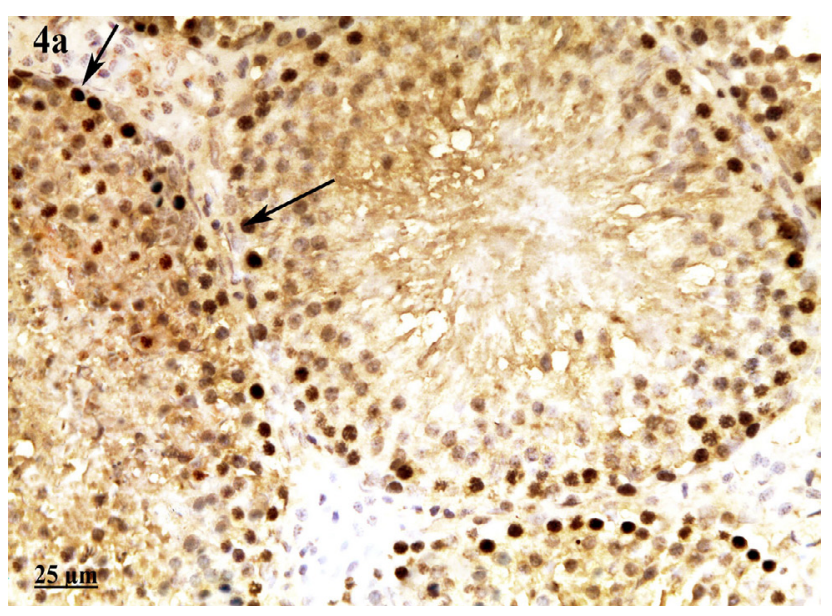

Fig. 4a: A photomicrograph of a section in the testis of group I showing many PCNA immunopositive germ cells in the seminiferous tubules (arrow) (immunostaining for PCNA $\times 400$, scale bar $=25 \mu \mathrm{m}$ ). 


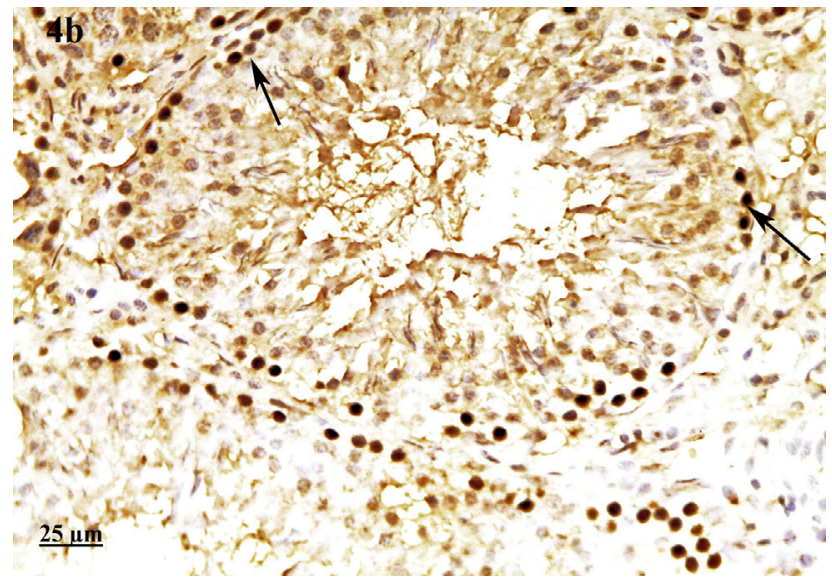

Fig. 4b: A photomicrograph of a section in the testis of group II showing moderate number of PCNA immunopositive germ cells in the seminiferous tubules (arrow) (immunostaining for PCNA $\times 400$, scale bar $=25 \mu \mathrm{m}$ ).

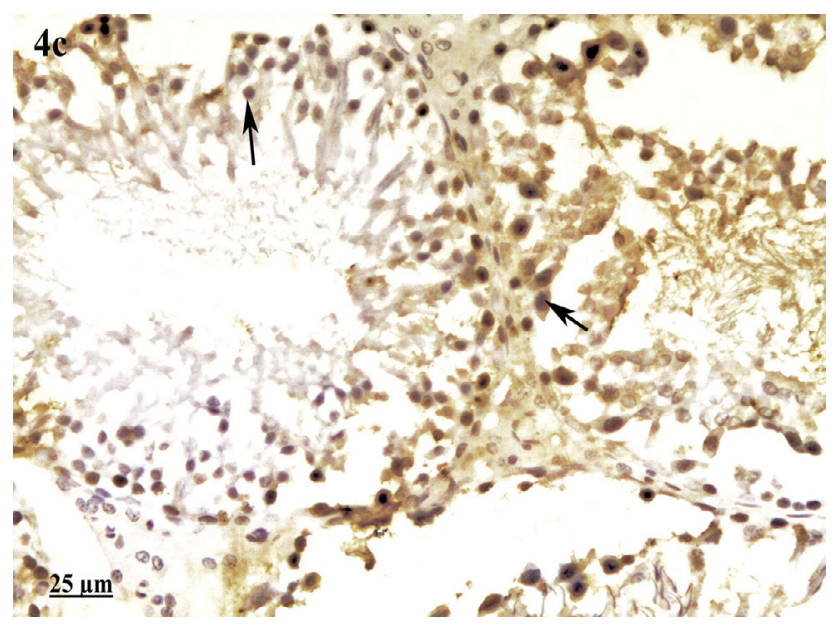

Fig. 4c: A photomicrograph of a section in the testis of group III showing few PCNA immunopositive cells in the seminiferous tubules (arrow) (immunostaining for PCNA $\times 400$, scale bar $=25 \mu \mathrm{m}$ ).

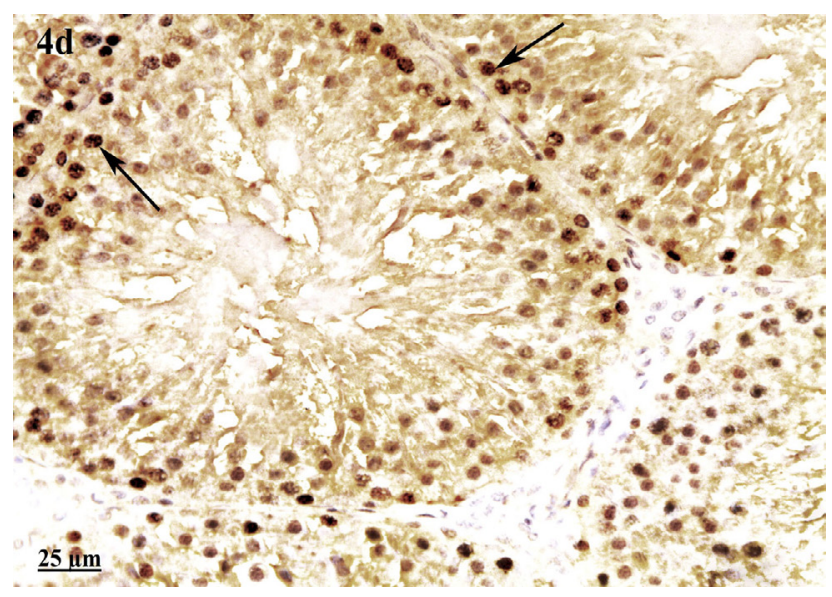

Fig. 4d: A photomicrograph of a section in the testis of group IV showing many PCNA immunopositive cells in the seminiferous tubules (arrow) (immunostaining for PCNA $\times 400$, scale bar $=25 \mu \mathrm{m}$ ).

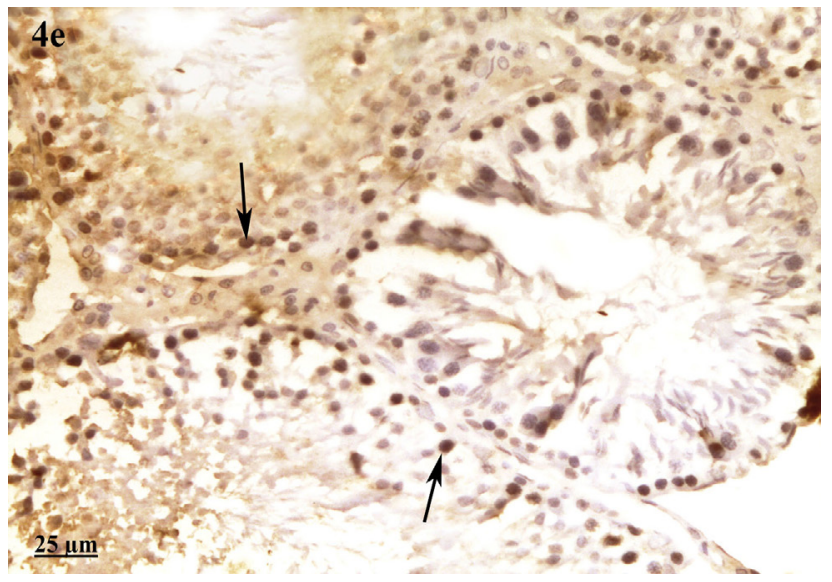

Fig. 4e: A photomicrograph of a section in the testis of group V showing moderate number of PCNA immunopositive germ cells in the seminiferous tubules (arrow) (immunostaining for PCNA $\times 400$, scale bar $=25 \mu \mathrm{m}$ ).

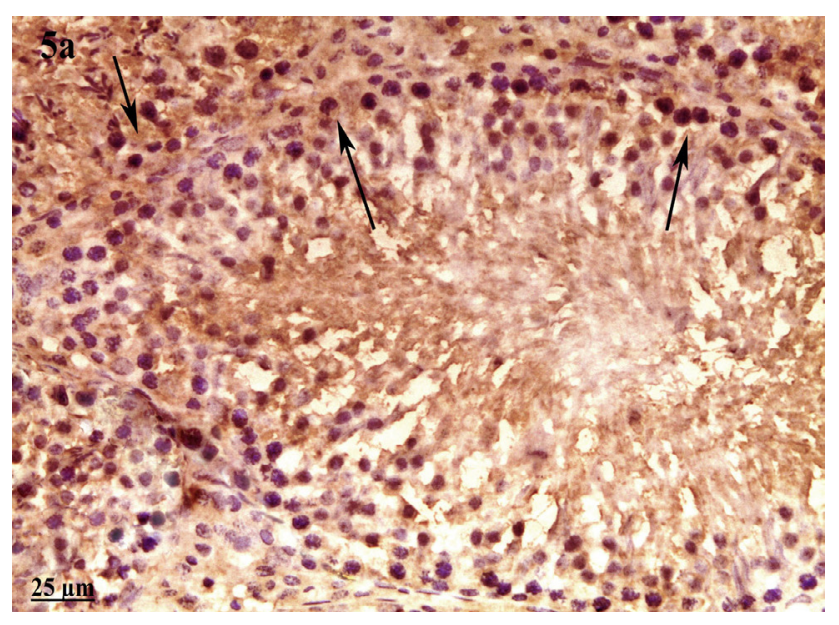

Fig. 5a: A photomicrograph of a section in the testis of group I showing intense positive Bcl-2 immunoreaction in cells of the seminiferous tubule (arrow) (immunostaining for Bcl-2 $\times 400$, scale bar $=25 \mu \mathrm{m}$ ).

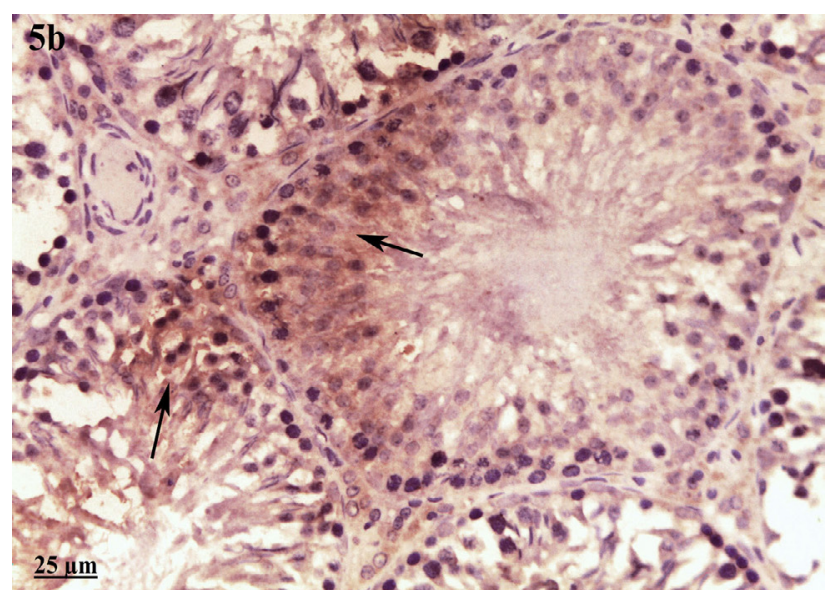

Fig. 5b: A photomicrograph of a section in the testis of group II showing moderate positive Bcl-2 immunoreaction in the cells of the seminiferous tubule (arrow) (immunostaining for Bcl-2 $\times 400$, scale bar=25 $\mu \mathrm{m}$ ). 


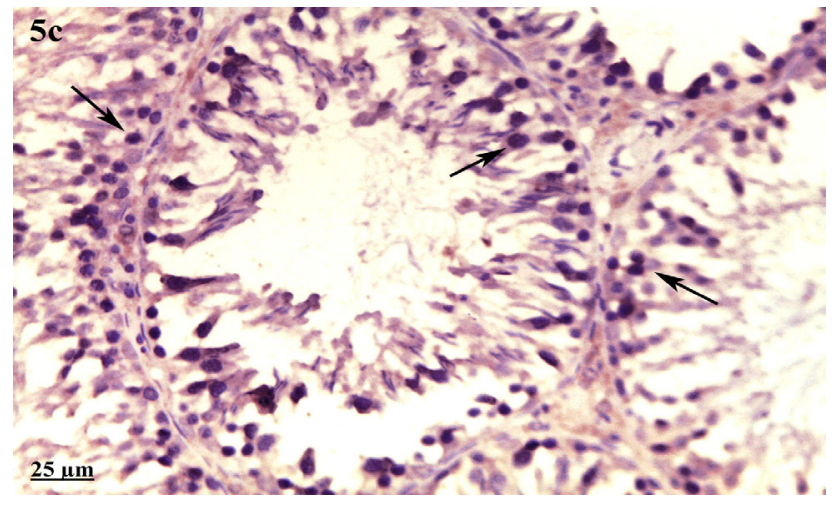

Fig. 5c: A photomicrograph of a section in the testis of group III showing minimal Bcl-2 immunoreaction in the cells of the seminiferous tubule (arrow) (immunostaining for Bcl- $2 \times 400$, scale bar $=25 \mu \mathrm{m}$ ).

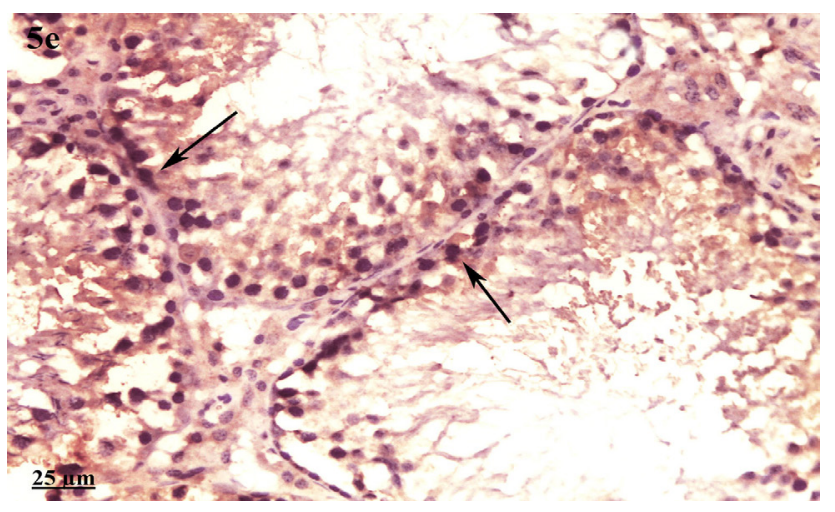

Fig. 5e: A photomicrograph of a section in the testis of group V showing mild positive Bcl-2 immunoreaction in the cells of the seminiferous tubule (arrow) (immunostaining for Bcl- $2 \times 400$, scale bar $=25 \mu \mathrm{m}$ ).

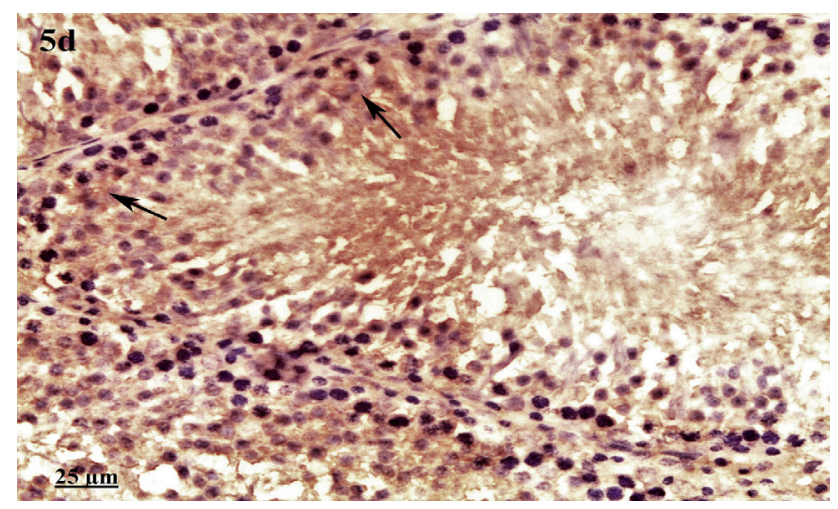

Fig. 5d: A photomicrograph of a section in the testis of group IV showing intense positive Bcl-2 immunoreaction in the cells of the seminiferous tubule (arrow) (immunostaining for Bcl-2 $\times 400$, scale bar $=25 \mu \mathrm{m}$ ).

Table 1: Comparison of blood testosterone levels in all groups

\begin{tabular}{lccccc}
\hline & Group I & Group II & Group III & Group IV & Group V \\
\hline Testosterone (ng/ml) & & & & & \\
Mean & 3.31 & 3.25 & 1.49 & 3.39 & 2.28 \\
SD & 0.4454 & 0.4117 & 0.3489 & 0.6103 & 0.2873 \\
Significance at $P<0.01$ & 3,5 & 3,5 & $1,2,4,5$ & 3,5 & $1,2,3,4$ \\
\hline
\end{tabular}

$1=$ sig. with group I $2=$ sig. with group II $3=$ sig. with group III $4=$ sig. with group IV $5=$ sig. with group V.

Table 2: Comparison between of MDA, GSH, and catalase (Cat.) levels in all groups

\begin{tabular}{|c|c|c|c|c|c|c|c|c|c|c|c|c|c|c|c|}
\hline & \multicolumn{3}{|c|}{ Group I } & \multicolumn{3}{|c|}{ Group II } & \multicolumn{3}{|c|}{ Group III } & \multicolumn{3}{|c|}{ Group IV } & \multicolumn{3}{|c|}{ Group V } \\
\hline & Mean & SD & Sig. & Mean & SD & Sig. & Mean & SD & Sig. & Mean & SD & Sig. & Mean & SD & Sig. \\
\hline $\mathrm{MD}$ & 15.1 & 0.4759 & $2,3,5$ & 23.1 & 0.6245 & $1,3,4$ & 35.9 & 1.0397 & $1,2,4,5$ & 16 & 1.9060 & $2,3,5$ & 22.2 & 0.4490 & $1,3,4$ \\
\hline $\mathrm{GSH}$ & 62.4 & 0.7309 & $2,3,5$ & 52.7 & 1.1408 & $1,3,4$ & 40.9 & 0.7077 & $1,2,4,5$ & 61.9 & 0.9366 & $2,3,5$ & 52.4 & 0.4140 & $1,3,4$ \\
\hline Cat. $\mathrm{U} / \mathrm{mg}$ protein & 7.1 & 0.2561 & $2,3,5$ & 5.9 & 0.2372 & $1,3,4$ & 2.9 & 0.1621 & $1,2,4,5$ & 7 & 0.3189 & $2,3,5$ & 5.7 & 0.2983 & $1,3,4$ \\
\hline
\end{tabular}

1=sig. with group I $2=$ sig. with group II $3=$ sig. with group III $4=$ sig. with group IV $5=$ sig. with group V. 
Table 3: Comparison of alpha smooth muscle actin immunoreactivity in all groups

\begin{tabular}{|c|c|c|c|c|c|}
\hline & Group I & Group II & Group III & Group IV & Group V \\
\hline Mean area $\%$ & $2.52 \%$ & $8.65 \%$ & $22.18 \%$ & $3.03 \%$ & $17.15 \%$ \\
\hline SD & 0.3606 & 0.6483 & 0.8289 & 0.7513 & 1.3331 \\
\hline Significance at $P<0.01$ & $2,3,5$ & $1,3,4,5$ & $1,2,4,5$ & $2,3,5$ & $1,2,3,4$ \\
\hline
\end{tabular}

1=sig. with group I $2=$ sig. with group II $3=$ sig. with group III $4=$ sig. with group IV $5=$ sig. with group V.

Table 4: Comparison of PCNA immunoreactivity in all groups

\begin{tabular}{lcccc}
\hline & Group I & Group II & Group III & Group IV \\
Mean area \% & $19.80 \%$ & $14.58 \%$ & $8.22 \%$ & $18.13 \%$ \\
SD & 1.0927 & 0.6865 & 0.3568 & 3.1302 \\
Significance at $P<0.01$ & $2,3,5$ & $1,3,4,5$ & $1,2,4,5$ & 0.6028 \\
\hline
\end{tabular}

1=sig. with group I $\quad 2=$ sig. with group II $\quad 3=$ sig. with group III $4=$ sig. with group IV $5=$ sig. with group V.

Table 5: Comparison of $\mathrm{Bcl} 2$ immunoreactivity in all groups

\begin{tabular}{|c|c|c|c|c|c|}
\hline & Group I & Group II & Group III & Group IV & Group V \\
\hline Mean area $\%$ & $41.71 \%$ & $24.11 \%$ & $10.70 \%$ & $39.83 \%$ & $15.74 \%$ \\
\hline SD & 0.4037 & 1.2703 & 0.5623 & 3.1744 & 0.6271 \\
\hline Significance at $P<0.01$ & $2,3,5$ & $1,3,4,5$ & $1,2,4,5$ & $2,3,5$ & $1,2,3,4$ \\
\hline
\end{tabular}

1=sig. with group I $\quad 2=$ sig. with group II $\quad 3=$ sig. with group III $4=$ sig. with group IV $5=$ sig. with group V.

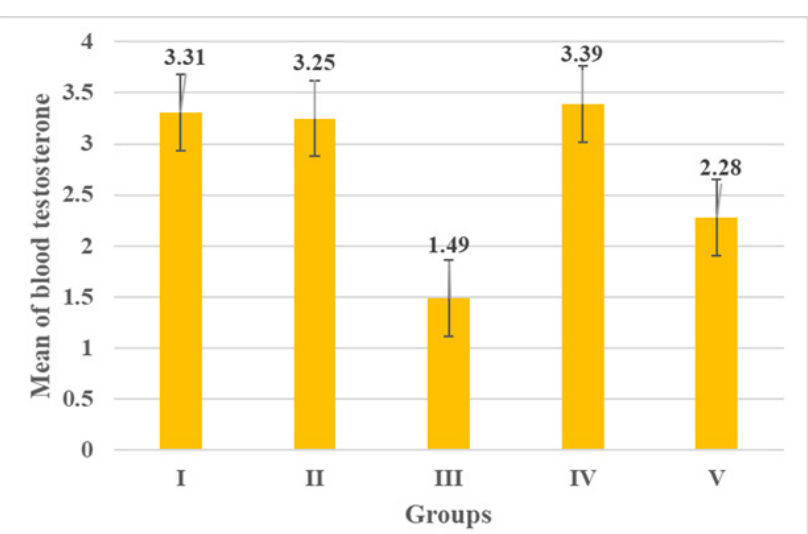

Histogram 1: Showing the mean of blood testosterone in all groups

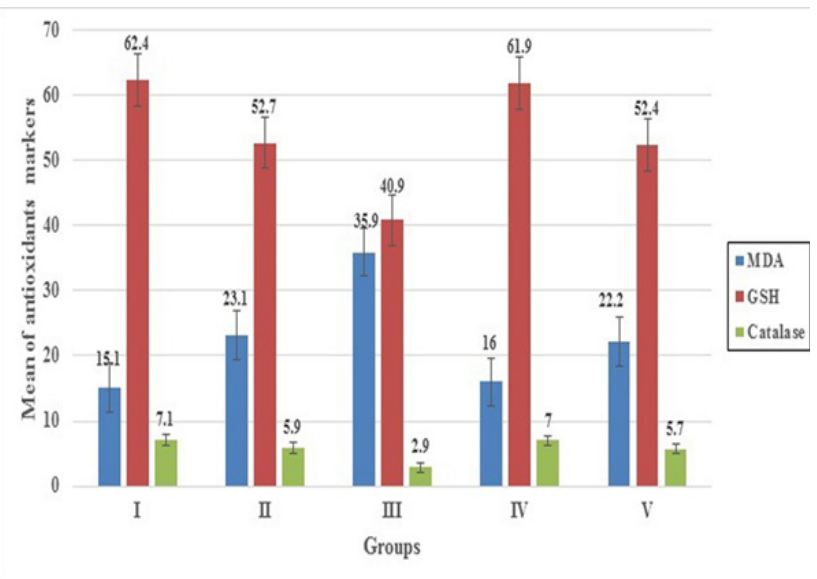

Histogram 2: Showing the mean of MDA, GSH and Catalase in all groups

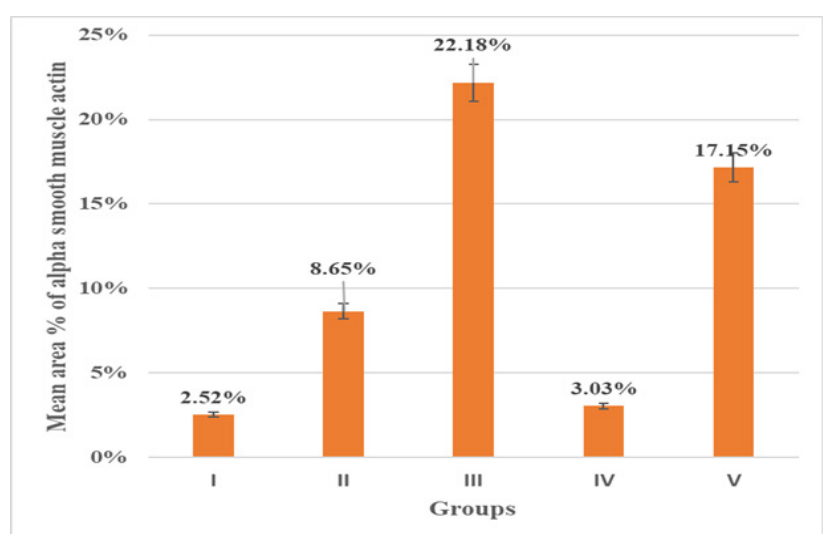

Histogram 3: Showing the mean area \% of alpha smooth muscle actin immunostaining for all groups

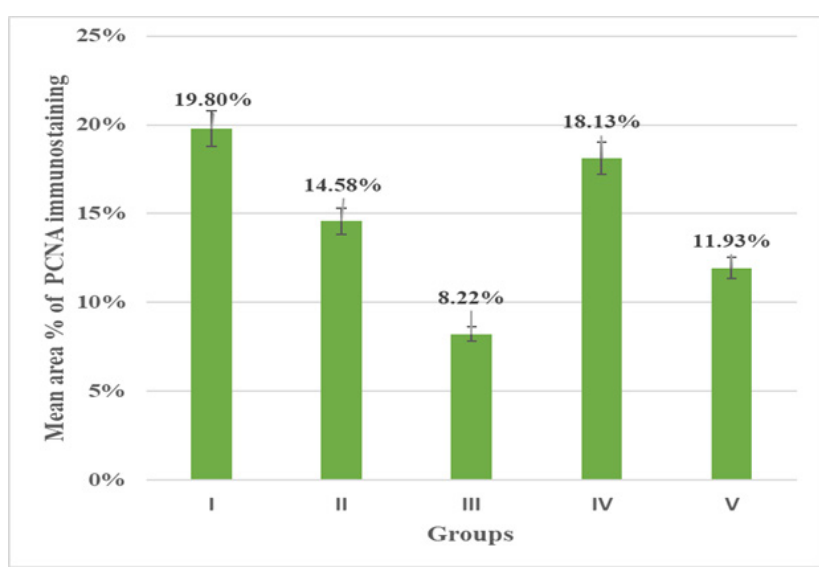

Histogram 4: Showing the mean area \% of PCNA immunostaining for all groups 


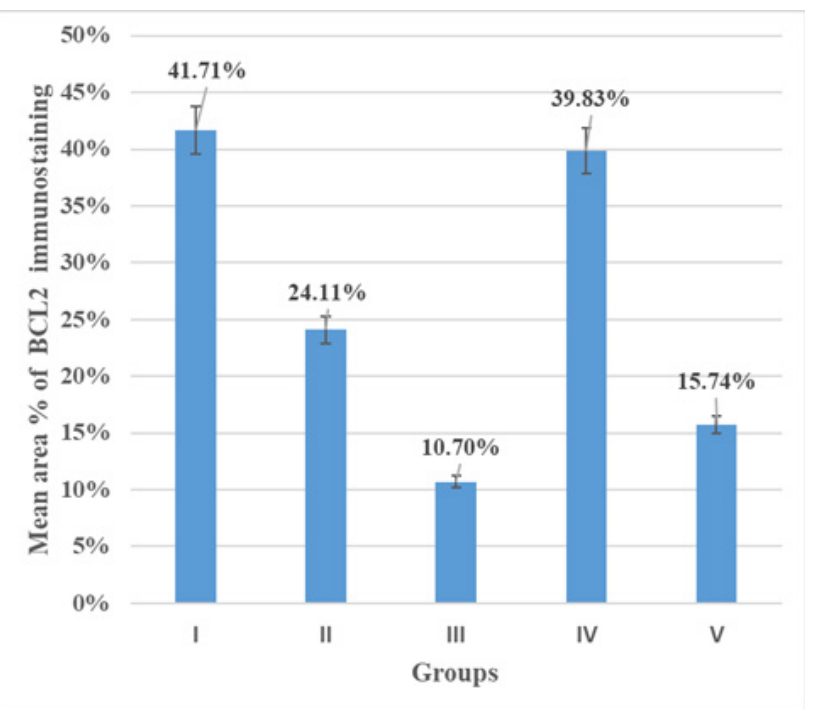

Histogram 5: Showing the mean area $\%$ of $\mathrm{Bcl} 2$ immunostaining in all groups

\section{DISCUSSION}

In the previous few years, metal NPs such as AgNPs have attracted a great technological interest because of their excellent properties. However, various concerns have been confirmed about their potential toxicity on distant organs $\mathbf{s}^{[0,32]}$.

In our experimental model, we chose intraperitoneal injection of AgNPs over other routes of administration because this route allows by passing absorption. Also, it is a fast route to deliver AgNPs to the circulation as a result of excessive blood and lymph vessels in the peritoneum ${ }^{[3,33]}$.

The results of light and immunohistochemical examination of sections from testis of groups II and III were dose-dependent and thus group II showed mild changes in comparison to group III. Group III revealed severe degenerative changes in the seminiferous tubules such as marked apparent reduction of the number, disorganization, and vacuolation of most germinal epithelial cells. Most cells of tubules had pyknotic nuclei and wide gaps between them. Some tubules had desquamated cells within their lumen. Interstitial tissue displayed few Leydig cells and vacuoles. There were dilated congested blood vessel and mononuclear cellular infiltration around tubules. Moreover, there was a significant increase $(P<0.01)$ of $\alpha$-SMA immunoreaction and a significant decrease $(P<0.01)$ of PCNA and Bcl-2 immunostaining in cells of the seminiferous tubule compared to control group.

Our findings were in accordance with several scientists who mentioned that AgNPs could cross the blood-testis barrier (BTB) and accumulate in the testes. Therefore, AgNPs produced a reduction in the number of different germinal cells and led to injury and disorganization of the seminiferous tubules ${ }^{[34,35]}$. Published literature revealed that silver nanoparticles were known to induce pyknosis of nuclei of germ cells due to breakdown and damage of DNA $^{[36,33]}$. Some reporters attributed the vacuolation to the premature exfoliation of the cells of the seminiferous tubules ${ }^{[37]}$. Other investigators explained that the detachment of germ cells may be owing to the marked disruption of the Sertoli cells interaction, followed by the sloughing of the germ cells from seminiferous epithelium ${ }^{[34,35]}$.

Many former studies demonstrated inflammatory mononuclear cell infiltration in many organs with silver nanoparticles toxicity, which may result from increasing the cytokines production, increasing $\mathrm{B}$ cell distribution, and inflammatory cell infiltrates ${ }^{[38,39]}$.

Alpha smooth muscle actin ( $\alpha$-SMA) is a component of the cytoskeleton and a specific marker for myoepithelial and smooth muscle cells ${ }^{[14,40]}$. It affects nearly all tissues in the body such as liver, lung, testis, kidney, heart, and pancreas $^{[41]}$. Immunopositive reaction for $\alpha$-SMA was demonstrated in PMCs around the seminiferous tubules and the smooth muscle cells of the wall of blood vessels. Our results agreed with previous researchers ${ }^{[40,41,42,43]}$ who reported a significant progressive increase of $\alpha$-SMA immunostaining with AgNPs. They added that lamina propria surrounding degenerated seminiferous tubules was thickened by the proliferation of myoid cells accompanied by an increase in collagen fibers deposition. Some PMCs changed morphologically into a swollen and irregular shape with abundant cytoplasmic organelles, then, they transformed into myofibroblasts.

Immunoexpression of PCNA in the testis is considered as a proliferative marker to estimate spermatogenesis. It has many values as a quick, reliable, sensitive, and quantitative method to determine and find early testicular toxicity ${ }^{[44,45]}$. Our findings were identical and confirming the findings of some scientists who reported significant decrease of PCNA immunostaining with AgNPs. This was clarified by increased apoptosis and depletion of the active DNA contents in the dividing spermatogenic cells ${ }^{[46,47,48]}$.

Apoptosis is a biological complex process that is needed for regulating cell survival through elimination of diseased or dead cells ${ }^{[49,7]}$. One of the antiapoptotic proteins is Bcl-2 that belong to Bcl-2 family and have vital function in triggering the apoptosis pathway by maintaining mitochondrial structure and function ${ }^{[50,51,52]}$. Our findings were supported by former workers ${ }^{[53,54]}$ who clarified that Bcl-2 is pivotal for normal spermatogenesis and determines whether apoptosis takes place in cells exposed to damage. Exposure to AgNPs leads to production of reactive oxygen species (ROS) accompanied by oxidative, cytotoxic and genotoxic events. Accumulation of ROS and the activation of oxidizing enzymes lead to cell membrane, mitochondrial damages and germ cell apoptosis ${ }^{[35]}$.

The hormonal analysis of Group III in the present study showed a significant diminishing of testosterone level $(p<0.01)$. Testosterone is essential for the normal spermatogenesis and preserves the structural morphology and the normal physiology of seminiferous tubule ${ }^{[48]}$ Our hormonal results coincide with other studies which attributed that to a direct effect at Leydig cell or an indirect 
effect by disturbing the hormonal level at hypothalamicpituitary axis. Finally, it can lead to an increase in sperms of abnormal shapes and a decrease in sperm viability ${ }^{[55,56]}$.

Current findings indicated that intraperitoneal injection of silver nanoparticles in groups II and III causes a significant increase in the level of lipid peroxidation (MDA) $(p<0.01)$ and a significant reduction in the activity of antioxidant enzymes $(p<0.01)$ such as GSH and catalase compared to control group that is considered a state of oxidative stress in testicular tissue. Our results agreed with those of prior researches who stated that AgNPs produced significantly high concentrations of reactive oxygen species that lead to decline of the testicular antioxidant enzymes, induce the oxidative damage of testicular cellular membranes, and finally induce a harmful effect of on spermatogenesis ${ }^{[11,57]}$.

Our biochemical findings are supported by the histopathological observations of the testis.

Most of the scientific reports suggested that the most possible mechanism of action of silver nanoparticles toxicity is related to induction of oxidative stress and lipid peroxidation which in turn triggers cellular changes such as DNA damage, apoptosis, and cytokine production. The toxic effects of AgNPs were dose dependent. Several studies concluded the cytotoxicity of AgNPs to the mitochondrial activity that increased with the increase in the dose and concentration of AgNPs causing severe reduction of mitochondrial function, enhanced membrane leakage, necrosis, and stimulation of apoptosis ${ }^{[58,59]}$.

Group IV of current research revealed a marked improvement proven by the histological, immunohistochemical, hormonal, and morphometric results. On the other hand, group $\mathrm{V}$ showed some improvement of the histological changes. There was a significant moderate increase $(P<0.01)$ of $\alpha$-SMA immunoreaction and a significant decrease $(p<0.01)$ of PCNA and Bcl-2 immunostaining in cells of the seminiferous tubule compared with group I. Testosterone level in group V was significantly decreased $(p<0.01)$ compared with group I and significantly increased $(p<0.01)$ as compared with group III.

Preservation of the histological structures with camel milk was explained by many investigators who stated that camel milk could prevent cell injury and tissue damage caused by toxic agents through stimulation of the antioxidant system $^{[14,60,20]}$. Recent evidence suggests that camel milk has high content of vitamins (effective antioxidants) such as vitamins $\mathrm{E}$ and $\mathrm{C}$ and also chelating agents used for curing of heavy elements toxicity ${ }^{[61]}$.

Camel milk contains effective components such as proteins, fats, sugar, vitamins, salts, and other substances helping in the building and growth of the body. Additionally, it preserves and limits tissue damage ${ }^{[22]}$. Camel milk effectively inhibits the production of proinflammatory cytokines such as TNF- $\alpha$, IL-1, and IL-6 in mononuclear cells. It also has a serious role in DNA replication, transportation, and protein synthesis and cell division and differentiation ${ }^{[62]}$.

The improvement of testosterone may be attributed to the high content of vitamin $\mathrm{C}$ in $\mathrm{CM}$ which leads to suppression of hydroxyl radical generation and scavenging of free radical, thus prohibiting lipid peroxidation. Moreover, $\mathrm{CM}$ is rich in zinc and magnesium which facilities absorption and metabolism of other potent antioxidants such as vitamins $\mathrm{E}$ and $\mathrm{C}^{[19,63]}$.

Groups IV and V of the current study revealed a significant decrease of MDA level $(p<0.01)$ and a significant increase in the levels of GSH and catalase $(p<0.01)$ as compared to groups II and III, respectively. Similar observations were detected by other investigators who stated that the antioxidant activity of CM is due to the existence of lactoferrin in its contents and the presence of camel a-lactalbumin. It has many antioxidant vitamins in high concentrations such as vitamins B2, C, E, and A and plenty of trace elements, like magnesium and zinc ${ }^{[23,63]}$.

Several researches ${ }^{[14,15,19]}$ stated that the most important mechanism of CM against toxic induced oxidative stress is due to its potent antioxidant activities such as superoxide dismutase, catalase, and glutathione reductase. Other studies $^{[23,64]}$ described that the lactoferrin and the camel a-lactalbumin in CM are important agents for increasing antioxidant properties of CM.

\section{CONCLUSION}

Silver nanoparticles toxicity induced dose-dependent structural degenerative changes in testis. Camel milk may be useful in ameliorating the biochemical and histopathological changes caused by AgNPs toxicity as a result of enhancing antioxidant defense system. Contact with high dosage of AgNPs is better to be avoided. However, further clinical studies with human populations for long periods are still needed to emphasize the results obtained from animal studies.

\section{CONFLICT OF INTEREST}

There are no conflict of interest.

\section{REFERENCES}

1. Salah M and Abdul-Hamid M. Protective effect of orange and grapefruit peel extracts against testicular toxicity induced by sulfasalazine in male albino rats. the Egyptian Journal of Histology 2014; 37:429-441.

2. Yousef MM, Helal OK and AdlyN. Histological study of the effect of paracetamol on the seminiferous tubules of adult rabbits: light and electron microscopy. the Egyptian Journal of Histology 2011; 34:790-799.

3. Garcia TX, Costa GMJ, França LR, and Hofmann MC. Sub-acute intravenous administration of silver nanoparticles in male mice alters Leydig cell function and testosterone levels. Reprod. Toxicol.2014;45:59-70. 
4. Luaibi NM and Qassim HA. Dose and time dependent effects of silver nanoparticles (AGNPS) on ovarian histology and serum levels of sex hormones in female rats. Pak. J. Biotechnol.2017;14(4):663-672.

5. Mazen NF, Saleh EZ, Mahmoud AM and Shaalan AA. Histological and immunohistochemical study on the potential toxicity of sliver nanoparticles on the structure of the spleen in adult male albino rats. the Egyptian Journal of Histology 2017;40(3):374-378.

6. Heydarnejad MS, Samani PY, Dehkordi MM, Shadkhast M, Rahnama S. Histopathological effects of nanosilver (Ag-NPs) in liver after dermal exposure during wound healing. Nanomed. J. 2014;1(3): 191-197.

7. Iyiola OA, Olafimihan TF, Sulaiman FA, Anifowoshe AT. Genotoxicity and histopathological assessment of silver nanoparticles in Swiss albino mice. UNED Research Journal 2018;10(1):90-97.

8. El Mahdy MM, Salah Eldinb TA, Aly HS, Mohammed FF, Shaalan MI. Evaluation of hepatotoxic and genotoxic potential of silver nanoparticles in albino rats. Experimental and Toxicologic Pathology 2014; 67:21-29.

9. Roda E, Barni S, Milzani A, Dalle-Donne I, Colombo $\mathrm{G}$ and Coccini T. Single Silver nanoparticle instillation induced early and persisting moderate cortical damage in rat kidneys. Int. J. Mol. Sci.2017;18(2115):1-15.

10. Fatemi M, Moshtaghian J, Ghaedi K, Jafari dinani $\mathrm{N}$ and Naderi G. Effects of silver nanoparticle on the developing liver of rat pups after maternal exposure. Iranian Journal of Pharmaceutical Research 2017;16(2):685-693.

11. Attia AA. Evaluation of the testicular alterations induced by silver nanoparticles in male mice: biochemical, histological and ultrastructural studies. Research Journal of Pharmaceutical, Biological and Chemical Sciences 2014;5(4):1558-1589.

12. Gherkhbolagh MH, Asari MJ, Alizadeh Z, Sohrabi M, In vivo induced nephrotoxicity of silver nanoparticles in rat after oral administration. J. Res. Med. Dent. Sci. 2018;6(1):43-51.

13. Liao C, Li Y and Tjong SC. Bactericidal and cytotoxic properties of silver nanoparticles. Int. J. Mol. Sci. 2019;20(449):1-47.

14. Gabr SA, Zahran F, Mohammed Faten F, Hassanin WF, Sharoud MN and Mesalam NM. Therapeutic effect of camel milk against hepatotoxicity induced by CCL4 in rats. Research Journal of Pharmaceutical, Biological and Chemical Sciences (R.J.P.B.C .S.)2018;9(1):601-614.

15. Ali MZ, Qureshi AS, Usman M, Kausar R and Ateeq MK. Comparative effect of camel milk and black seed oil in induced diabetic female albino rats. Pak. Vet.J.2017;37(3):293-298.
16. Hassan NS and Emam MA. Protective effect of camel milk and Ginkgo Biloba extract against alloxan-induced diabetes in rats. J. Diabetes Metab. 2012;3(10):1-8.

17. Kebir NE, Aichouni A, Zahzeh T. Raw camel milk properties on alloxan-induced diabetic wistar rats. Rom. J. Diabetes Nutr. Metab.Dis.2017;24(1): 041-047.

18. Arab HH, Salama SS, Maghrabi IA. Camel milk ameliorates 5-fluorouracil- induced renal injury in rats: targeting MAPKs, NF- $\kappa \mathrm{B}$ and PI3K/Akt/eNOS pathways. Cell Physiol. Biochem.2018;46:1628-1642.

19. Zahran F, Gabr SA, Abd El-Moneim AE, Sharoud MN, Hassanin WF, Mesalam NM. Prophylactic effect of camel milk on physiological and biochemical changes in CCL4-intoxicated rats. Journal of Experimental Biology and Agricultural Sciences techniques.2018; 6(1):211- 219 .

20. Zuberu J, Saleh MIA, Alhassan AW, Adamu BY, Aliyu M, Iliya BT. Hepatoprotective effect of camel milk on poloxamer 407 induced hyperlipidemic wistar rats. Open Access Maced. J. Med. Sci.2017;5(7):852-858.

21. Hamed H, Gargouri M, Bellassoued K, Akrouti A, ElFeki A and Gargouri A. Hepato-preventive activity of camel milk against CCl4-induced lesions in mice. Res. Rev. Biosci. 2017;12(2):1-12.

22. Khaleel ZI, Ahmed AH, Thamer RH. study the therapeutic effect of camel milk on liver toxicity experimentally developed in white mice Mus Musculus. international journal of sciences: Basic and Applied Research (I.J.S.B.A.R) 2017;35(3):249-258.

23. El-Sawy HBI, Soliman MM, El-Shazly SA, Ali HA. Protective effects of camel milk and vitamin E against monosodium glutamate induced biochemical and testicular dysfunctions. Progress in Nutrition 2018;20(1):76-85,

24. Turkevich J, Stevenson PC, Hiller J. A study of the nucleation and growth processes in the synthesis of colloidal gold. Discuss. Faraday Soc.1951;11: 55-75.

25. Lee, P. C., Meisel, D. Adsorption and surface enhanced Raman of dyes on silver and gold sols. Journal of Physical Chemistry 1982;86(17): 3391-3395.

26. Bancroft JD and Layton C. The hematoxylin and eo $\neg$ sin, In: Suvarna SK, Layton C and Bancroft JD, editors. Bancroft's Theory and practice of histological 7th edition. Churchill Livingstone: Philadelphia. 2013:173-212.

27. Jackson $P$, Blythe D. Immunohistochemical techniques [chapter 8]. In: Suvarna SK, Layton C, Bancroft JD, editors. Theory and practice of histological techniques. 7th ed. Philadelphia: Churchill Livingstone of Elsevier. 2013: 381-434. 
28. Elkhateeb SA, Mazen NF, Ibrahim OY and AbdelFattah NF. Assessment of the protective role of vitamin $E$ in atrazine toxicity on the testis of adult albino rats: a histological and biochemical study. the Egyptian Journal of Histology 2014; 37:442-452.

29. Ohkawa H., Ohishi N, Yagi K. Assay for lipid peroxides in animal tissues by thiobarbituric acid reaction. Analytical Biochemistry 1979; 95:351- 358.

30. Beutler E, Duron O, Kelly MB. Improved method for the determination of blood glutathione. Lab Clin. Med.1963; 61:882-888.

31. Aebi, H. Catalase in Vitro. In: Packer, L., Ed., Methods Enzymol, Academic Press, New York,1984:121-126.

32. Brohi RD, Wang L, Talpur HS, Wu D,Khan FA, Bhattarai D, Rehman ZU, Farmanullah F and Huo LJ. Toxicity of nanoparticles on the reproductive system in animal models: A Review. Front. Pharmacol.2017;8(606):1-23.

33. Fathi N, Hoseinipanah SM, Alizadeh Z, Assari MJ, Moghimbeigi A, Mortazavi M, Hosseini MH, Bahmanzadeh M. The effect of silver nanoparticles on the reproductive system of adult male rats: A morphological, histological and DNA integrity study. Adv. Clin. Exp. Med.2019;28(3):1-7.

34. Thakur M, Gupta H, Singh D, Mohanty I, Maheswari $\mathrm{U}$, Vanage $\mathrm{G}$ and Joshi DS. Histopathological and ultrastructural effects of nanoparticles on rat testis following 90 days (Chronic study) of repeated oral administration. Journal of Nanobiotechnology 2014;12(42):1-13

35. Ahmed SM, Abdelrahman SA Shalaby SM. Evaluating the effect of silver nanoparticles on testes of adult albino rats (histological, immunohistochemical and biochemical study). J. Mol. Hist.2017; 48:9-27.

36. Al-naqeeb G, Bajilan S, Baqer M, Fakhreldin MR. Effect of silver nanoparticles on the ovary of PCOinduced female mice: A histopathological study. G.J.B.B.2017 ;6(4):623-630

37. Sabbah WS, Kamal FHM, Elsayed OA and Abd-Elaty OA. Effect of vitamin E on medroxyprogesterone acetate toxicity in some organs of white albino rats: a histopathological study. The Egyptian Journal of Histology 2016; 39:109-123.

38. Pani JP, Mishra SP, More RS, Singh S, Singh R. Hepatotoxic effect of characterized silver nanoparticle. International Journal of Therapeutic Applications $2015 ; 29: 13-18$.

39. Wen H, Dan M, Yang Y, Lyu J, Shao A, Cheng X. Acute toxicity and genotoxicity of silver nanoparticle in rats. PLoS ONE 2017;12(9):1-16.

40. Moustafa AM. Age-related changes in the immunohistochemical localization pattern of $\alpha$-smooth muscle actin and vimentin in rat testis. the Egyptian Journal of Histology 2012; 35:412-423

41. Ahmed RA. Histological assessment and quantification of hypervitaminosis A-induced fibrosis in liver, kidney and testis of albino rats. World J. Pharm. Sci. 2017;5(8):209-220.

42. Nicolas, N, Michel V, Bhushan S, Wahle E, Hayward S,Ludlow H, Kretser DM. Testicular activin and follistatin levels are elevated during the course of experimental autoimmune epididymo-orchitis in mice. Sci. Rep. 2017;7(42391):1-15.

43. Tröndle I, Westernströer B, Wistuba J, Terwort N, Schlatt Sand Neuhaus N. Irradiation affects germ and somatic cells in prepubertal monkey testis xenografts. Molecular Human Reproduction 2017;23(3):141-154.

44. Reda SM, Hashem HE, Elnegris HMand Elshal LM. Role of bone marrow derived mesenchymal stem cells in protection of spermatogenic and Sertoli cells against histological alterations induced by torsion/detorsion in rats. journal of medical histology 2017;1(2):154-169.

45. Elmallah MIY, Elkhadragy MF, Al-Olayan EM and Abdel Moneim AE. Protective effect of Fragaria Ananassa crude extracton cadmium-induced lipid peroxidation, antioxidant enzymes suppression, and apoptosis in rat testes. Int. J. Mol. Sci. 2017;18(957): $1-16$.

46. Abdel Aziz HO, Elsayed HM and Ali MA. Effect of mobile phone radiation on proliferation and apoptosis in rabbit testes: a histological and immunohistochemical study. The Egyptian Journal of Histology 2015; 38:670-678.

47. Ismail DI. Histological study on doxorubicin-induced testicular toxicity and the protective role of sesamol in rats. The Egyptian Journal of Histology 2016; 39: 38-49.

48. Sakr S.A.1, Bayomy M.F.F.1, Gendia S.E. Protective impact of basil (Ocimum basilicum) on adriamycin induced reproductive toxicity in male albino rats. International Journal of Pharmaceutical and Medical Research 2017;5(2):8-14.

49. El-Mahalaway AM. Protective effect of curcumin against experimentally induced aflatoxicosis on the renal cortex of adult male albino rats: a histological and immunohisochemical study. Int. J. Clin. Exp. Pathol. 2015;8(6):6019-6030.

50. Mosadegh M, Hasanzadeh S, Razi M. Nicotineinduced damages in testicular tissue of rats; evidences for bcl-2, p53 and caspase-3 expression. Iran J. Basic Med. Sci. 2017;20:199-208.

51. Mousa AM, El-Mahalawa AM and El-Desoky RE. The protective effects of sodium hyaluronate on corneal injuries induced by chlorinated water in adult male rabbits: A histological and immunohistochemical 
study. The Egyptian Journal of Histology 2018;41(2):140-149.

52. Chakraborty K, Dey A, Bhattacharyya A, Dasgupt SC: Anti-fibrotic effect of black tea (Camellia sinensis) extract in experimental pulmonary fibrosis. Tissue and Cell 2019;56:14-22.

53. Anan HH, Wahba NS, Abdallah MA and Mohamed DA. Histological and immunohistochemical study of cyclophosphamide effect on adult rat testis. Int. J. Sci. Rep.2017;3(2):39-48.

54. Ning JZ, Li W, Cheng F, Rao T, Yu WM, Ruan Y, Yuan $\mathrm{R}$, Zhu SM. The protective effects of GYY4137 on testicular torsion/detorsion injury in rats. Int. J. Clin. Exp. Med.2018;11(4):3387-3395.

55. Farag EA and Yousry MM. Effect of mobile phone electromagnetic waves on rat testis and the possible ameliorating role of Naringenin: A histological study. The Egyptian Journal of Histology 2017;41(1): 108-121.

56. El-Sokkary GH, Hareedy HHG and Youns HAM. Protective role of melatonin on the effect of diazepam on proliferative activity, morphological changes and testosterone levels in the testes of rats. Journal of Histology and Histopathology 2018;5(5):1-9.

57. Mohamed HRH. Studies on the genotoxicity behavior of silver nanoparticles in the presence of heavy metal cadmium chloride in mice. Journal of Nanomaterials2016; 2016:1-12.
58. Yang L, Kuang H, Zhang W, Aguilar ZP, Wei H and $\mathrm{Xu} \mathrm{H}$. Comparisons of the biodistribution and toxicological examinations after repeated intravenous administration of silver and gold nanoparticles in mice. Scientific Reports 2017;7 (3303):1-12

59. Al-Bishri WM. Toxicity study of gold and silver nanoparticles on experimental animals", Pharmacophore 2018;9(1):48-55.

60. Al-Fartosi K and Humaidan NH. Hepatoprotective properties of camel's milk against benzene induced toxicity in male rats. European Journal of Pharmaceutical and Medical Research 2015;2(6): 33-37.

61. Oudah LK. The effect of camel milk in the tissue changes to the kidneys of laboratory male rats treated by cadmium. International Journal of Animal Health and Livestock Production Research 2016;1(2):8-14.

62. Khan AA and Alzohairy MA. Hepatoprotective effects of camel milk against CCl4-induced hepatotoxicity in rats. Asian Journal of Biochemistry2011; 6:171-180.

63. Zakaria AD, Bayad AS, Abdel-Raheem SM, AlBusadah KA and Albokhadaim I. Camel's milk improves the semen characteristic in immobilization stressed rats. Asian Journal of Animal Sciences 2016;10: 139-146.

64. Abubakar AL, Dandare A, Dandare SU, Rabiu S, Ibrahim AS, Armaya'u S. Effect of camel milk supplementation in management of gastric ulcer. Applied Medical Research 2018;4(1):12-17. 
الملخص العربى

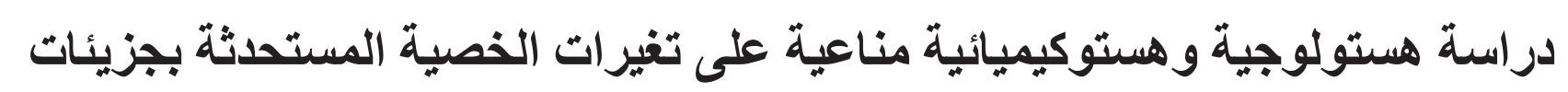

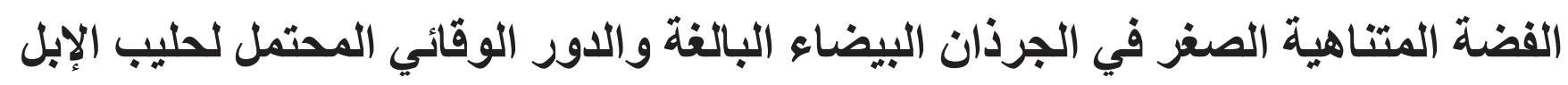

\author{
نهلة العراقي العزب وعبير مصطفي المحلاوي \\ قسم الأنسجة و بيولوجيا الخلية ـ كلية الطب ـ جامعة بنها
}

المقدمة: تستخدم جزيئات الفضة المتناهية الصغر بشكل واسع في الطب وصناعة المو اد الغذائية، ومصحوبه باحتمالية تأثير ها السمي في العديد من الأعضاء. ويعتبر حليب الإبل مصدر ممتاز لتغذية اللأنسان وله العديد من الفو ائد الصحية ولئة

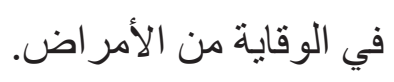
الهدف من البحث: تقييم تأثنير جر عات مختلفة من جزيئات الفضة المتناهية الصغر على خصية الجرذان البالغة والدور الوقائي المحتمل لحليب الإبل. الطريقة وخطة العمل: وقد تم تقسيم خمس و أربعون من ذكور الجرذان البالغين إلى خمس مجمو عات: المجمو عة الأولى:

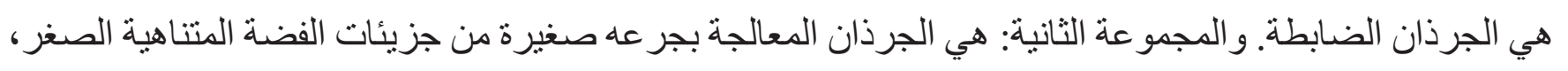
و المجمو عة الثالثة: هي الجرذان المعالجة بجر عه كبيرة من جزيئات الفضة المتناهية الصغر ، بينما المجمو عة الر ابعة: هي الجرذان المعالجة بجر عه صغيرة من جزيئات الفضة المتناهية الصغر و حليب الإبل، أما المجمو عة الخامسة: هي هي الجرذان المعالجة بجر عه كبيرة من جزيئات الفضة المتناهية الصغر وحليب الإبل. وقد أخذت عينات الخصيه وتمت ولتيه معالجتها باستخدام التقنيات الهستولوجية و الهستوكيميائية المناعية. وقد اجري فحص لهرئية لهرمون التستوستيرون. و وأجريت الدر اسات المورفومنرية و التحليل الإحصائي.

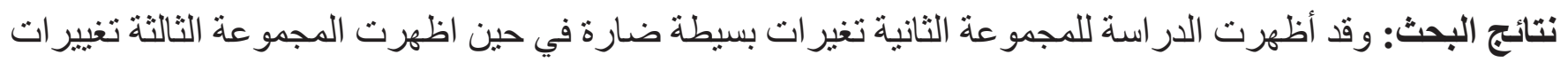
شديدة ضارة على الأنابيب المنوية. و أظهرت زيادة ذو دلالة احصائية في التفاعل المناعي للبروتين اكتين ألفا للعضلة الملساء (P>01)

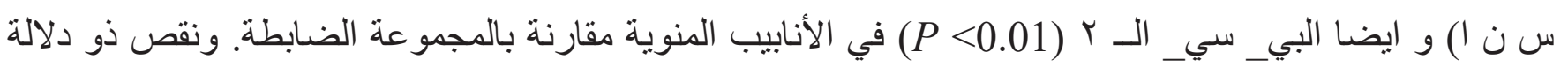
احصائية في التستوستيرون (0.01) التي وصفت سابقا. الاستنتاج: أحدثت جزيئات الفضة المتتاهية الصغر تغير ات تركيبية في الخصيه مرتبطة بالجر عة. وقد كان حليب الأبل قادر علي تقليل التغير ات الكيمبائية و الهستوباثو لجية الناجمةعن جزيئات الفضة المتناهية الصغر بو اسطة تأثيره كمضاد 